\title{
TLR1 Gene
}

National Cancer Institute

\section{Source}

National Cancer Institute. TLR1 Gene. NCI Thesaurus. Code C24862.

This gene is involved in pathogen recognition and in the activation of innate immunity. 